\title{
Erratum
}

Cold Spring Harb Symp Quant Biol 82 (2017) doi: 10.1101/sqb.2017.82.034298

\section{Erratum: Cellular and Molecular Mechanisms of Centromere Drive}

\author{
Michael A. Lampson and Ben E. Black \\ Correspondence: lampson@sas.upenn.edu; blackbe@pennmedicine.upenn.edu
}

When this article was first published, the email address of author Ben E. Black was incorrect. The publisher apologizes for this error. The email address has been corrected above and in the current version of the article. 


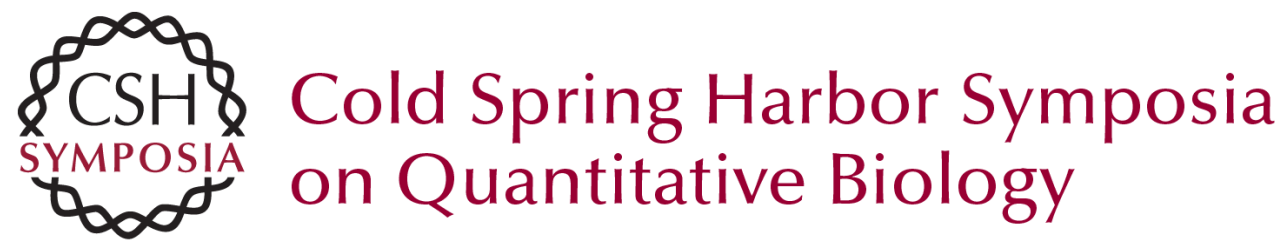

\section{Erratum: Cellular and Molecular Mechanisms of Centromere Drive}

Michael A. Lampson and Ben E. Black

Cold Spring Harb Symp Quant Biol 2017 82: originally published online February 26, 2018 Access the most recent version at doi:10.1101/sqb.2017.82.034736

\section{Related Content Cellular and Molecular Mechanisms of Centromere Drive Michael A. Lampson and Ben E. Black Cold Spring Harb Symp Quant Biol UNKNOWN , 2017 82: 249-257 \\ Open Access Freely available online through the Cold Spring Harbor Symposia on Quantitative Biology Open Access option. \\ License \\ Email Alerting \\ Receive free email alerts when new articles cite this article - sign up in Service the box at the top right corner of the article or click here.}

